\title{
Licensing Standard Essential Patents and the German Federal Supreme Court Decisions FRAND Defence I and FRAND Defence II
}

\author{
Peter R. Slowinski
}

Published online: 18 November 2021

(C) The Author(s) 2021

\section{Introduction}

It may be argued that the modern saga of the licensing of standard essential patents (SEPs) on fair, reasonable and non-discriminatory (FRAND) terms in Europe started with the Orange Book Standard decision of the German Federal Supreme Court in $2009^{1}$ and reached a preliminary climax with the ruling from the Court of Justice of the European Union (CJEU) in Huawei/ZTE in $2015 .^{2}$ The first decision set a benchmark with a strong tendency in favor of the patent holder, and the second put things more into balance by setting out a procedure as to how the owner of an SEP and implementers of standard-encumbered technologies could arrive at FRAND-compliant license agreements in the shadow of patent remedies. While Huawei/ZTE provided an apparently fair but rather broad framework for the negotiation, many questions regarding the details remained. In the aftermath of the CJEU decision, national courts particularly in the UK and Germany tried to fill the gaps based on the facts of specific cases, and patent holders as well as implementers tried to test the boundaries of how far they could go. However, it was not until 2020 that cases came up through the instances and reached the UK Supreme Court ${ }^{3}$ and the German Federal Supreme Court. ${ }^{4}$ This finally provided the latter with the

\footnotetext{
${ }^{1}$ German Federal Supreme Court, case No. KZR 39/06, decision of 6 May 2009.

2 Huawei v. ZTE, C-170/13, ECLI:EU:C:2015:477.

3 Unwired v. Conversant [2020] UKSC 37.

${ }^{4}$ Federal Supreme Court decision of 5 May 2020 - KZR 36/17 (FRAND Defence I), for a translation of this decision into English see this issue of IIC at https://doi.org/10.1007/s40319-021-01125-y; and Federal Supreme Court decision of 24 November 2020 - KZR 35/17 (FRAND Defence II), for a translation of this decision into English see this issue of IIC at https://doi.org/10.1007/s40319-021-01126-x.
}

P. R. Slowinski $(\bowtie)$

J.S.M. (Stanford); Junior Research Fellow and Doctoral Student, Max Planck Institute for Innovation and Competition, Munich, Germany

e-mail: peter.slowinski@ip.mpg.de 
opportunity to review its own Orange Book case law in light of the CJEU decision. The Court could also provide guidance to the lower instances in their quest for balance between right holders and implementers.

Since both decisions are printed in this issue of the IIC, I will omit a summary and focus on an analysis of the most important points. Also, since the question of infringement was not really an issue in both cases, I will also not address the technical side of the cases but concentrate on the questions of SEP/FRAND licensing that have been discussed by the Court in some length. Finally, I will highlight two important issues in the area of SEPs that are currently widely discussed topics in a number of jurisdictions but which did not play a role in FRAND Defence I and FRAND Defence II but which may come up in future cases.

\section{Balance of Interests and Balance of Power}

The crucial point with respect to SEP/FRAND licensing negotiations and the respective litigation is the balance of interests between the patent owner and the implementer of the standard as well as the balance of their respective powers. This has already been addressed by the CJEU. The German Federal Supreme Court also pays close attention to these parameters by acknowledging that the patent owner has a dominant market position due to the fact that a patent becomes standard essential and implementers cannot rely on the standard without using the teaching of the patent. Therefore, in principle, they need to acquire a license from the patent holder. However, as the Court also rightly points out, while the implementer can request such a license from the patent owner, the patent owner cannot force the implementer to sign a license agreement. ${ }^{5}$ The only means that the patent owner has to compel the implementer to take a license is - at the very end - an injunction. Therefore, while initially the patent owner may be in the stronger position, in the end the implementer can drag out negotiations indefinitely for its own economic benefit. The two extreme positions of power are also known as "hold-up" by the patent owner and "hold-out" by the implementer.

\subsection{Willing Licensee and Negotiation Dance}

To avoid both hold-up and hold-out, the Federal Supreme Court finds that a negotiated solution is the best possible outcome. ${ }^{6}$ While the Court acknowledges that independent bodies can decide the issue of FRAND terms, it strongly believes that the patent owner and the implementer, as market participants, are in the best position to arrive at license terms which are fair, reasonable and non-discriminatory. In this regard, there is little room for dispute with the Court's opinion, since a decision on FRAND terms requires knowledge of the respective products and markets. Therefore, an arbitrary tribunal or court will, in the end, need to obtain the relevant information from the parties if it has to decide the question. And even if the

\footnotetext{
5 FRAND Defence I (supra note 4), para. 70.

6 FRAND Defence I (supra note 4), para. 81.
} 
case ends in front of a third-party tribunal, the negotiation history can provide a valuable basis for the final decision. Therefore, the negotiation dance between the parties is not only the best possible way to find a balanced solution but is crucial in any case.

While the German Federal Supreme Court took substantial time to analyse the negotiation in the present two cases, the bottom line is fairly simple and starts with the guidelines provided by the CJEU. The patent owner has to inform the implementer of the alleged infringement and the requirement to acquire a license. ${ }^{7}$ This is the first step in the negotiation dance. The second step is for the implementer to express its willingness to accept such a license ${ }^{8}$ before the third step in which the patent owner has to present a specific and written license offer. ${ }^{9}$ In this regard, the CJEU was very clear and the German Federal Supreme Court follows its guidelines. The main question in both FRAND decisions of the Federal Supreme Court is how such willingness can be demonstrated.

The CJEU expressly stated that the alleged infringer must diligently respond to the (written) license offer, "in accordance with recognized commercial practices in the field and in good faith" and without delaying tactics. ${ }^{10}$ If taken literally, it may be implied from this that such a diligent reaction is only required with respect to the written offer and not with respect to the initial information regarding the infringement and the possibility of a FRAND license. However, such a literal view does not seem to be in line with reality and was probably not intended by the CJEU. The question as to how the initial willingness to acquire a license must be expressed simply did not come up in the Huawei case. But since the CJEU refers to recognized commercial practices in the field and good faith negotiations, it seems fair and reasonable to use this standard when evaluating whether the willingness to acquire a license was sincere or merely a delaying tactic. This is the route that the Federal Supreme Court follows.

Based on the facts of the present cases, the Court points out that the willingness may not only be a formal expression but that it must be backed up by the behaviour of the implementer and that furthermore it needs to be present throughout the negotiation process just as the willingness to grant a FRAND license must be present on the side of the patent owner throughout the process. ${ }^{11}$ This does not mean that both initial offers must be absolutely FRAND from the very beginning, but that both parties must have and show the willingness to move together to a negotiated license on FRAND terms. For the implementer this means that it must react to the initial offer with the speed that parties under such circumstances can expect. Waiting with an initial response for months does not sufficiently demonstrate the willingness to conclude a license agreement. This is particularly so if, as was the case in the FRAND Defence I case, the patent is about to expire and the implementer

\footnotetext{
7 Huawei v. ZTE (supra note 2), para. 61.

${ }^{8}$ Huawei v. ZTE (supra note 2), para. 63.

9 Ibid.

${ }^{10}$ Huawei v. ZTE (supra note 2), para. 65.

11 FRAND Defence I (supra note 4), para. 83.
} 
therefore knows that the patent owner will definitely loose the injunction as means to compel the implementer to take a license.

Therefore, the decisions by the Federal Supreme Court do not run contrary to the CJEU decision. Indeed, they interpret the guidelines provided by the EU court in light of its intensions for the negotiation dance to be a multi-step process in which both parties move towards a FRAND-based agreement in good faith and without exploitation of the respective power bases of hold-up and hold-out.

\subsection{Portfolio Licensing}

A second question, apart from the negotiation dance, is that of portfolio licensing. SEP owners usually do not want to license each SEP individually but instead they offer portfolio licenses. Such licenses tend to include not only SEPs but also patents that are in some way related to the standardized technology but not necessarily essential for the implementation of the standard. Here again, it is important to take into account the objective interests of the parties. Both, the patent owner and the implementer, under normal circumstances will want to reduce transaction costs and conclude only one license agreement after one negotiation. Acquiring licenses patent-by-patent and possibly country-by-country does not make economic sense unless of course the implementer actually does not need individual patents or the coverage of particular geographic areas. The first scenario is unlikely if the patents are SEPs. The second is also not very likely in cases where the implementer is a globally active company.

Similar to the UK Supreme Court ${ }^{12}$ the German Federal Supreme Court reaches the conclusion that global portfolio licenses are an established commercial practise as far as the licensing of SEPs in the telecommunications sector is concerned. ${ }^{13}$ The Court argues that it is in the objective interest of the patent owner to license to the implementer all patents that it requires to legally implement the standard even if such patents are not the issue of infringement proceedings between the parties. ${ }^{14}$ However, while the patent owner may base the calculation of royalties on all SEPs in the portfolio, the Federal Supreme Court points out that a FRAND-compliant license agreement may not require the licensee to pay for non-essential patents.

While this latter part of the ruling seems reasonable, some doubts remain as to how it fits into the objective interests of the parties and the realities of licensing negotiations. The court seems to be of the opinion that the non-essential patents are being licensed for free as part of the overall package. This may of course be beneficial from the point of view of the implementer. But where is the interest of the patent owner to license non-essential patents (i.e. patent law and competition law do not require him to license to anyone) for free? The assumption that such patents will not influence the overall license fee in some way seems therefore very far-fetched and theoretical. Of course, it will be difficult to prove otherwise, but it would be interesting to see if this comes up in future cases.

\footnotetext{
12 Unwired v. Conversant (supra note 3), para. 15.

13 FRAND Defence I (supra note 4), para. 78.

14 Ibid.
} 


\subsection{Uniform Tariff}

A third point that has been raised in both Federal Supreme Court cases, and which is regularly being raised in litigation involving SEPs and FRAND terms, is the question of whether or not the patent owner must offer a uniform tariff to all willing licensees. Implementers argue that the "non-discriminatory" part of FRAND requires absolutely equal treatment of all implementers and that this in turn must lead to a uniform tariff for everyone. The Federal Supreme Court and also other courts $^{15}$ do not share this view. Instead, the courts allow the patent owner to differentiate based on the individual situation of the implementers and the circumstances that lead to the conclusion of a license agreement. ${ }^{16}$ As the Federal Supreme Court points out, the FRAND declaration is not about equality but instead it is meant to ensure effective access to the standard. ${ }^{17}$ Therefore, there may not be any form of unjustified discrimination against license seekers, but there may be reasons why license terms differ from one licensee to another as long as effective access to the technology is ensured.

In this reasoning the German Federal Supreme Court is not alone; it is also supported by the UK Supreme Court, ${ }^{18}$ and the reasoning seems to be correct. First of all, patent license agreements are usually rather complex and involve more than the variable "royalty rate". Second, the patent owner may decide to grant a reduction in license fees or more favourable conditions to early implementers as a form of a first-mover advantage, and differential license terms are not automatically discriminatory. ${ }^{19}$ Finally, other factors such as pressure from government authorities may lead to an objectively unjustified reduction in the royalty rate or other preferential treatment. While this may result in distortion of competition, it is not a consequence of the patent owner's voluntary behaviour and should therefore not affect its ability to charge higher but objectively justified fees from other implementors. As the Federal Supreme Court puts it, such pressure can constitute an attack on the commercial interests of the patent owner and the patent owner "must be able to react to such an attack in a reasonable manner". ${ }^{20}$ However, the Court points out that such conduct may "not aim at the strengthening of the dominant position and its abuse". ${ }^{21}$ While this is certainly true, it does not exclude the possibility that such conduct, as a reaction to pressure, will distort competition. But this is the result of economic nationalism that leads to pressure from governments.

\footnotetext{
15 Unwired v. Conversant (supra note 3).

16 FRAND Defence I (supra note 4), para. 81.

17 Ibid.

18 Unwired v. Conversant (supra note 3).

19 Unwired v. Conversant (supra note 3), para. 105 et seq.

20 FRAND Defence I (supra note 4), para. 101.

21 FRAND Defence I (supra note 4), para. 102.
} 


\section{Counterclaim for Damages}

There is one aspect of the FRAND Defence I decision that the Court only mentions en passant towards the end of the ruling but that it found important enough to include in the official headnotes which are supposed to highlight the most important legal principles in a decision. According to the ruling, the implementer of an SEP may have a claim for damages against the owner of the SEP for non-fulfilment of the duty to grant a license on FRAND terms. ${ }^{22}$ While the Court did not grant the (counter) claim for damages brought by the implementer in this case, it did set out the requirements that such a claim must meet: the implementer can only claim damages if it requests the patent owner to conclude a license agreement on FRAND terms and the patent owner does not react to this request in accordance with its obligations. $^{23}$ This claim for damages therefore supports the main claim for the conclusion of a license agreement that the willing implementer has against the owner of an SEP. What remains open, and did not have to be answered in the case at hand, is the question of how damages in such a situation should be calculated. This may be more difficult than one might imagine since, after all, the implementer has the factual possibility to use the patented technology, and in the case of an unwilling licensor, the claim for an injunction will be unenforceable. Therefore, the actual damage on the side of the willing licensee can only be the taint that the patent is used unlawfully and this use has a diminished value compared to a licensed use. It will be interesting to see if any such case will move through the instances in the future.

\section{Patent Ambush}

A final issue addressed by the Federal Supreme Court is the question of patent ambush. In a patent ambush situation, the patent owner is aware of the standardsetting process and the fact that its patent is relevant for the standard but neither informs the SSO of this fact nor submits a FRAND declaration. As a result, the SSO includes the patented technology into the standard without the safeguards for the implementers that follow from a FRAND declaration, and the patent owner may be in a position to charge excessive royalty rates from implementers who do not expect to be confronted with such a situation ("patent ambush").

The Federal Supreme Court had to address two questions: the first is whether the conduct of a previous patent owner can be held against the new patent owner; and second, whether the fact that the new patent owner has submitted a FRAND declaration changes anything. The Court answered the first question based on German patent law. Objections against a new patent owner can only be raised based on the very narrow Sec. 15(3) of the Patent Act, which provides that objections can only be against a successor in title and not just any new patent holder. ${ }^{24}$

\footnotetext{
22 FRAND Defence I (supra note 4), para. 111.

23 Ibid.

24 FRAND Defence II (surpa note 4), para. 131.
} 
However, this very limited protection of the (potential) licensee under German law was not decisive here. As explained, one of the key components of a patent ambush is the fact that the patent owner does not submit a declaration to license the patent on FRAND terms. However, even in a patent ambush situation, the new owner may correct this and file a FRAND declaration thus limiting itself. This happened in the present case, and according to the Federal Supreme Court this remedied the situation and ensured that the assertation of the patent does not restrict competition. $^{25}$ This seems to be a very sound reasoning indeed. In the end, it is the purpose of the standard-setting process and the requirement to submit a FRAND declaration to ensure that access to the standardized and patented technology is not restricted through unreasonably high license fees. As long as a FRAND declaration is either provided at some point in time prior to the assertation of the patent or if the (new) patent owner only claims a FRAND license even without submitting a FRAND declaration to the SSO, the implementer is in no worse a position than it would have been, had the declaration been submitted during the initial standardization process.

\section{Open Questions and Conclusions}

So, what is the bottom line regarding these two decisions from Germany's highest court? In my opinion, the decisions are far more balanced than some may think. The most important point is that the decisions take into account the interests of both parties - the patent owner and the implementer of the standard - and that it offers some additional guidance regarding the duties of both parties. In this regard, it is very much in line with the broader guidelines that were provided by the CJEU seven years ago. While the decisions may differ in some points from those in other jurisdictions, and particularly the UK, the broad strokes, however, point to the same principles, and there is no substantial divergence with respect to what FRAND actually is.

It is in the nature of court decisions that they can only answer those questions that a particular case raises and that the court remains silent on other important issues that may be related to the topics at hand. With respect to SEPs and FRAND there are primarily two major questions that are still waiting for answers from either the German Federal Supreme Court or the CJEU. The first question, which has already been raised not only in lower instances in Germany but also in jurisdictions such as China, France, the UK and the US, is that of the proper venue for SEP/FRAND disputes. Related to this question is the issue of anti-suit-injunctions (ASIs), antianti-suit-injunctions (AASI) and the possibly infinite number of additionally added "antis". It is doubtful whether any national or - in the case of the CJEU - regional court will be able to provide a satisfying and globally accepted answer. Indeed, forum shopping might end in a power play not only between the patent owner and implementers but also between courts.

\footnotetext{
${ }^{25}$ FRAND Defence II (supra note 4), para. 131.
} 
The second question that has not been addressed by the German Federal Supreme Court thus far refers to who should acquire an SEP/FRAND license. Licenses on patents relating to mobile communication standards are often first implemented on the level of a small component but ultimately also on the level of a consumer product. In the case of mobile phones, there has never seemed to be a real issue as to where licensing should take place. Usually, phone manufacturers - and to some extent network operators - acquire the licenses, and the license fees are based on the sales of final products. The Federal Supreme Court briefly discusses the question of company group licenses if the manufacturer and the distributer are part of the same company group but different legal entities. ${ }^{26}$ But this is not the real problematic issue. Instead, as communication standards move to new industries, such as the automobile industry, new players have entered the negotiations who do not accept the "old" rules, and auto manufacturers demand that licenses are granted on the chip-level and not the car-level. This means that the question moves away from which entity within a company group is entitled to take a license, to the question of which commercially independent market player can claim a license and whether the patent owner can choose freely, to whom to license. The Higher Regional Court of Düsseldorf was faced with such a case and referred it to the CJEU. Unfortunately, from the point of view of legal development, the parties settled and the reference was rendered moot. But the hope remains that either the CJEU or the German Federal Supreme Court will get the chance to provide an answer to this important question as well.

Finally, there is still a lot of room to fine tune the requirements for all parties concerned in the negotiation dance and therefore there is a high likelihood that the Federal Supreme Court will get other chances to shape the law on SEPs and FRAND, and that FRAND Defence I and FRAND Defence II will be followed by at least a few more numbers.

Funding Open Access funding enabled and organized by Projekt DEAL.

Open Access This article is licensed under a Creative Commons Attribution 4.0 International License, which permits use, sharing, adaptation, distribution and reproduction in any medium or format, as long as you give appropriate credit to the original author(s) and the source, provide a link to the Creative Commons licence, and indicate if changes were made. The images or other third party material in this article are included in the article's Creative Commons licence, unless indicated otherwise in a credit line to the material. If material is not included in the article's Creative Commons licence and your intended use is not permitted by statutory regulation or exceeds the permitted use, you will need to obtain permission directly from the copyright holder. To view a copy of this licence, visit http:// creativecommons.org/licenses/by/4.0/.

Publisher's Note Springer Nature remains neutral with regard to jurisdictional claims in published maps and institutional affiliations.

$\overline{26}$ FRAND Defence II (supra note 4), para. 118. 